\title{
Pathomorphological evaluation of hepatobiliary lesions in dogs and cats of Ankara region
}

\author{
Yanad Abou Monsef*, and Osman Kutsal \\ Department of Pathology, Faculty of Veterinary Medicine, Ankara University, Ankara, Turkey
}

\begin{abstract}
ABOU MONSEF, Y., O. KUTSAL: Pathomorphological evaluation of hepatobiliary lesions in dogs and cats of Ankara region. Vet. arhiv 91, 359-378, 2021.
\end{abstract}

\section{ABSTRACT}

The objective of this study was to investigate pathological disorders of the hepatobiliary system in dogs and cats in Ankara using pathomorphological methods, and to determine the types and frequency of the observed lesions. Furthermore, we aimed to evaluate hepatic reparation as a reaction of the liver to injury with different hepatobiliary lesions using immunohistochemical methods. Livers obtained from 56 cats and 74 dogs submitted for post-mortem investigation were examined macroscopically and microscopically. Samples with hepatic fibrosis were stained immunohistochemically with an $\alpha$-SMA antibody. Lesions were found in $98 \%$ of the livers of the examined dogs and cats. The most common histopathological diagnoses were hepatitis (39.28\%), hepatocellular lipidosis (16.07\%), and cholangitis/cholangiohepatitis (14.28\%) in cats. In dogs they were hepatitis (28.38\%), passive congestion (25.68\%) and proliferative lesions $(21.62 \%)$. For some hepatobiliary lesions, breed, age and gender predispositions were observed. Immunohistochemically, the $\alpha$-SMA antibody positively stained parenchymal, portal and septal myofibroblasts. A positive correlation was verified between immunohistochemical $\alpha$-SMA scores and histochemical fibrosis scores. This is the first study in Turkey documenting both the incidence of hepatobiliary lesions among feline and canine species, and their pathomorphological features. In terms of reparation, the major role of the hepatic myofibroblasts in liver fibrosis was observed. There were variations in the intensity and location of positively stained cells according to the type of lesion. The conclusion of this research indicates the need to pay attention to certain hepatic lesions in dogs and cats, and provides a reference standard for further clinical and histopathological studies.

Key words: cat; dog; hepatobiliary system; immunohistochemistry; pathomorphology

\section{Introduction}

Hepatobiliary diseases, commonly reported in dogs and cats, are of great importance due to the dependence of most organs on the metabolic function of the liver (BROWN et al. 2017). Canine and feline liver diseases are frequently underdiagnosed. Although ultrasonographic and biochemical methods are used in the diagnosis, the final diagnostic method remains histopathological
(ROTHUIZEN et al. 2006). Despite the retrospective histopathological surveys done in the United Kingdom (BAYTON et al. 2018), United States (WANG et al. 2004) and Japan (HIROSE et al. 2014) on canine and feline hepatobiliary diseases, no similar data reporting the frequency of these diseases have been published in Turkey.

\footnotetext{
*Corresponding author:

Yanad Abou Monsef, DVM; PhD, Department of Pathology, Faculty of Veterinary Medicine, Ankara University, Ankara, Turkey, Phone: +90 (312) 317 0315; E-mail: yanad.abou.monsef@gmail.com
} 
The World Small Animal Veterinary Association (WSAVA) Liver Standardization Group recommended criteria for histopathological diagnosis of canine and feline hepatobiliary diseases to ensure uniformity of terminology (ROTHUIZEN et al. 2006). Since then, retrospective studies on canine and feline hepatobiliary diseases have been using these criteria as a guide in diagnosis. Liver diseases were classified in general terms into vascular, biliary, parenchymal and neoplastic disorders (ROTHUIZEN et al. 2006).

The liver is an organ with high resistance and regeneration abilities. Following injury, it initiates tissue repair with two balanced reactions, regeneration and reparation, to regain physiological function (BROWN et al. 2017, CULLEN and STALKER 2016). Although the exact mechanism of hepatic fibrosis is not fully known, myofibroblasts are thought to play a major role in its pathogenesis. The best known hepatic myofibroblasts are stellate cells that share the properties of smooth muscle cells. However, there are other important groups of myofibroblasts, such as portal / septal myofibroblasts, bone marrow-derived cells, and hepatocytes, capable of acquiring a mesenchymal phenotype by epithelial-mesenchymal transition (IJZER et al. 2006, SCHOTANUS et al. 2009).

The aims of this study were to: (1) conduct a comparative histopathological evaluation of hepatobiliary lesions in dogs and cats in Turkey (Ankara region); (2) describe the macroscopical and microscopical findings of these lesions; (3) evaluate hepatic fibrosis in different hepatobiliary lesions using histochemical and immunohistochemical methods; (4) investigate the immunohistochemical properties of hepatic myofibroblasts, as well as their role in hepatic fibrosis, if any; and (5) compare the variations of the intensity and localization of these cells according to the type of disease.

\section{Materials and methods}

Liver samples were obtained from dogs and cats submitted to the Pathology Department of Ankara University, Faculty of Veterinary Medicine for routine post-mortem examination between April 2017 and September 2018 (ethical approval protocol no-2016-23-197 by Ethical Committee of
Ankara University). Fifty-six cats and seventy-four dogs were included. The species, breed, gender and age of the animals were noted. After macroscopical examination of the liver, 2-3 mm thick samples were taken from all lobes. Portal lymph nodes showing lesions were also sampled.

Samples were fixed in $10 \%$ neutral buffered formalin, routinely processed and embedded in paraffin. Sections $(4 \mu \mathrm{m})$ were routinely stained with Harris's haematoxylin and eosin (H\&E). Histopathological evaluation was based on the WSAVA histological criteria. For further characterization of the lesions, special histochemical stains such as Periodic Acid-Schiff (PAS), AFIP method for lipofuscin, Oil red staining, Sudan Black staining and Perl's Prussian Blue staining methods were used. Additionally, liver samples with hepatic fibrosis (18 dogs and 12 cats) were stained with Masson's trichrome stain and scored semiquantitively using a modified staging system based on the staging systems proposed by GOODMAN (2007), ISHAK et al. (1995) and VINCE et al. (2016) (Table 1). Following this, the same slides were immunohistochemically stained with $\alpha$-SMA antibody (Thermo Fisher clone 1A4, ready-to-use) using the avidin-biotin complex peroxidase method.

For immunohistochemistry, $4 \mu \mathrm{m}$ sections were mounted on charged glass slides, dewaxed and rehydrated with xylol and graded alcohols. Heatinduced antigen retrieval was performed: sections were incubated in citrate buffer for 15 minutes in a microwave oven followed by cooling for $15 \mathrm{~min}$ at room temperature. Endogenous peroxidase activity was blocked in $3 \% \mathrm{H}_{2} \mathrm{O}_{2}$ (15 min), and unspecific background staining was omitted with blocking serum (35 min). Egg white and milk powder were used to block endogenous biotin (KUTLU and ALCIGIR 2019, MILLER 2001). Sections were incubated with the primary antibody for $1 \mathrm{~h}$ at $37{ }^{\circ} \mathrm{C}$. The biotin-streptavidin based detection system (Ultravision Quanto Detection System HRP, mouse and rabbit IgG, Thermo scientific) was used for secondary labelling (35 min each), and the reaction was visualized with aminoethyl carbazole substrate. Sections were counterstained with Gill's haematoxylin. Positive controls consisted of normal canine and feline liver sections. Negative controls were performed by replacing the antibody with PBS. 
In this research, we used the level $\alpha=0.05$ for the Pearson Chi-Square statistics to evaluate the independence between fibrosis and $\alpha$-SMA staining scores when using crosstabulation (also known as a bivariate table). Crosstabulation offers simultaneous distributions of two categorical variables. The Independence Test evaluates whether there is a relationship between the two variables by comparing the observed pattern in the classes with the pattern to be expected if the variables are truly independent from each other.

Table 1. Scoring system for hepatic fibrosis

\begin{tabular}{|l|l|}
\hline Stage & Fibrosis \\
\hline 0 & No fibrosis \\
\hline 1 & Fibrous expansion of most portal tracts, with or without short fibrous septa \\
\hline 2 & Fibrous expansion of most portal tracts with bridging (portal portal) septa \\
\hline 3 & Marked bridging (portal-portal or portal-central) with architectural distortion \\
\hline 4 & Lobular dissection (generalized isolation of hepatocytes into small clusters) or cirrhosis \\
\hline
\end{tabular}

\section{Results}

Of the 74 canine liver samples in this study, various lesions were detected in 73 samples. The three most frequent canine liver histopathological diagnoses were hepatitis $(28.38 \%)$, passive congestion $(27.03 \%)$ and proliferative lesions $(21.62 \%)$. Out of the 56 feline liver samples, lesions were detected in 55 samples. The three feline hepatic histopathological diagnoses encountered most were hepatitis (39.28\%), hepatocellular lipidosis (16.07\%) and cholangitis/ cholangiohepatitis $(14.28 \%)$. Detailed results of the various encountered hepatic pathological conditions and their frequencies are summarized in Tables 2 and 3.

Non-proliferative liver lesions. Hepatitis, which was the most frequent liver lesion in both dogs and cats, accounted for $28.38 \%$ and $39.28 \%$ of all canine and feline diagnoses, respectively. The subclassification frequencies of hepatitis cases are detailed in Tables 2 and 3. Histologically, fibrosis was present in all cases of chronic hepatitis. Acute hepatitis cases, with severe necrosis and regeneration, were diagnosed as fulminant hepatitis.

Cirrhosis was detected in four of the 74 dogs. One of the cases that showed excessive shrinking and histologically extensive replacement of the hepatic parenchyma with fibrous and adipose tissue, was diagnosed as atrophic cirrhosis (Fig. 1).
The histological features of non-specific reactive hepatitis were mainly portal inflammatory infiltrations composed of lymphocytes, plasma cells and/or neutrophil leucocytes without hepatic necrosis.

In the examination of all the hepatitis cases, a median age of 10 years old for canine chronic hepatitis and cirrhosis was noticed. Females (7 cases, $63.63 \%$ ) were more susceptible than males, and the breeds that might be at more risk were German Shepherd (2/11 cases), Golden Retriever (2/11 cases) and crossbreed dogs (2/11 cases). Nonspecific reactive hepatitis was found in cats with a median age of 4 months. British Shorthair and Tabby cats were more susceptible (3/6 - 2/6 cases), but no gender predisposition was seen.

Cholangitis/cholangiohepatitis was the third most common diagnosis in cats accounting for $14.28 \%$ of all the feline cases. All cholangitis/ cholangiohepatitis cases were diagnosed as lymphocytic. Cases confirmed with lymphocytic cholangitis/cholangiohepatitis mostly had a focal lymphocytic infiltration surrounding the bile ducts (Fig. 2A). Two cases, where the lymphocytic infiltration was restricted to the portal tracts, were diagnosed as lymphocytic cholangitis. Six cases, in which the portal lymphocytes infiltrated the adjacent parenchyma as well, were diagnosed as lymphocytic cholangiohepatitis. 

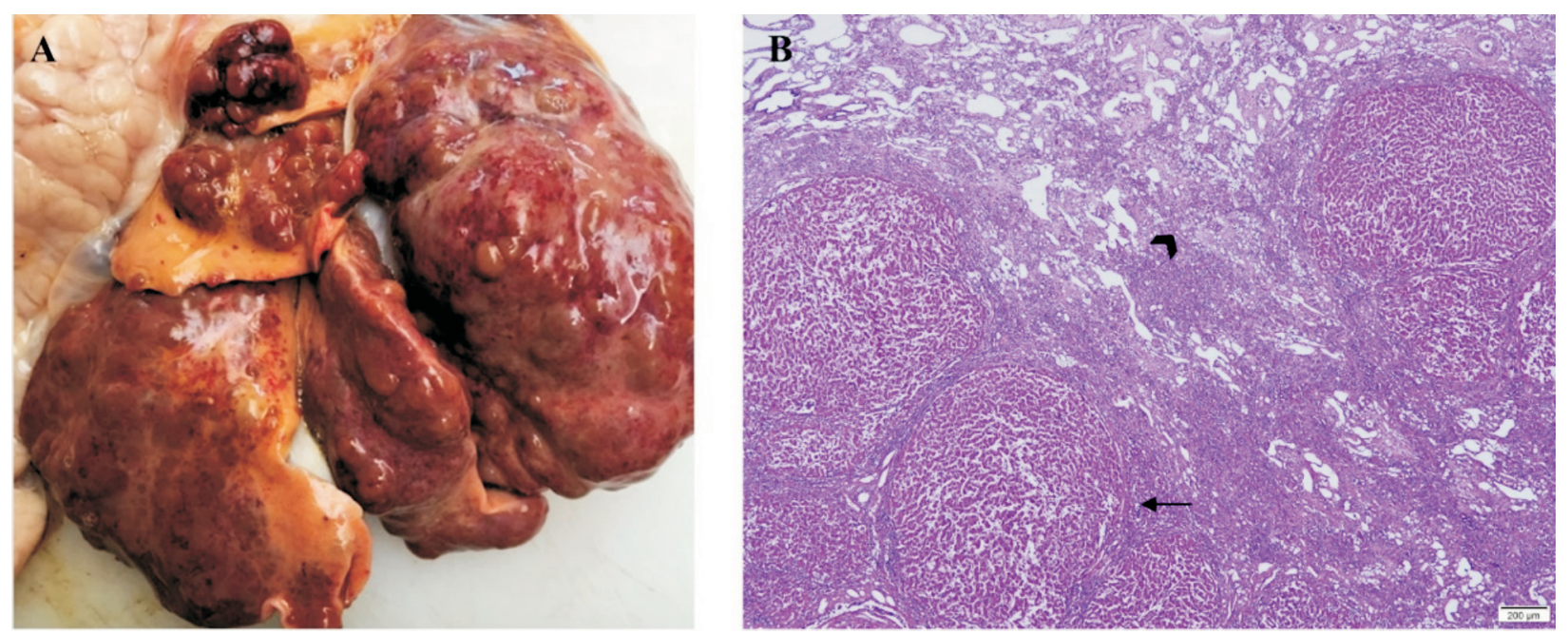

Fig. 1. A - Atrophic cirrhosis, Dog. B - Pseudolobules (arrow) surrounded by fibrous strands and adipose tissue (arrowhead) replacing the normal parenchyma, H\&E.

Biliary duct proliferation and peribiliary portal fibrosis were found in most of the cases. In dogs, one case of cholangitis was diagnosed, and it was classified as destructive cholangitis. Histologically, destruction of the bile ducts, peribiliary infiltration of neutrophil leucocytes, lymphocytes and pigment laden macrophages, in addition to cholestasis, were noticed (Fig. 2, B).

Table 2. Distribution of feline hepatobiliary diseases

\begin{tabular}{|l|c|c|}
\hline Histopathological diagnosis & Number of cases & Percentage of total cases \\
\hline Developmental disorders & $\mathbf{1}$ & $\mathbf{1 . 7 9 \%}$ \\
Congenital polycystic disease & 1 & $1.79 \%$ \\
\hline Hepatic displacements & 2 & $3.57 \%$ \\
\hline Vacuolar hepatopathy & 9 & $\mathbf{1 6 . 0 7 \%}$ \\
Hepatocellular steatosis & 9 & $16.07 \%$ \\
\hline Cholestasis (jaundice) & 1 & $1.79 \%$ \\
\hline Necrosis & 1 & $1.79 \%$ \\
\hline Autolysis & 1 & $1.79 \%$ \\
\hline Circulatory disorders & $\mathbf{6}$ & $\mathbf{1 0 . 7 1 \%}$ \\
Passive congestion & 6 & $10.71 \%$ \\
\hline Hepatitis & $\mathbf{2 2}$ & $\mathbf{3 9 . 2 8 \%}$ \\
Acute hepatitis & 5 & $8.93 \%$ \\
Subacute hepatitis & 9 & $16.07 \%$ \\
Chronic hepatitis & 2 & $3.57 \%$ \\
Non-specific reactive hepatitis & 6 & $10.71 \%$ \\
\hline Cholangitis/Cholangiohepatitis & $\mathbf{8}$ & $14.28 \%$ \\
Lymphocytic cholangitis/cholangiohepatitis & 8 & $\mathbf{7 . 1 4 \%}$ \\
\hline Proliferative lesions & $\mathbf{4} \%$ \\
Hepatocellular adenoma & 1 & $1.79 \%$ \\
Metastatic lymphoma & 3 & $5.35 \%$ \\
\hline No abnormality & 1 & $1.79 \%$ \\
\hline
\end{tabular}

* percentage of total cases: the number of cases of a diagnosis/the total number of cases $\times 100$ 
Lymphocytic cholangitis/cholangiohepatitis was diagnosed more frequently in Crossbreed and Tabby cats, with a median age of 2 years 5 months old, and no gender predisposition was observed.

Vacuolar hepatopathy was diagnosed in 7 canine livers $(9.46 \%)$, and 9 feline cases $(16.07 \%)$. All feline vacuolar hepatopathy cases were diagnosed as hepatocellular steatosis while those in the canine species were relatively evenly distributed between hepatocellular steatosis, hepatocellular swelling and hepatic glycogenosis. Grossly, the examined livers with mild hepatocellular steatosis showed an increase in size and a prominent lobular pattern while livers with severe hepatocellular steatosis were yellow and fragile in consistency (Fig. 3, A). On the microscopical level, clear lipid vacuoles were seen within the cytoplasm of the hepatocytes. The remnants of lipid vacuoles were positively stained with special dyes, such as Oil red staining and Sudan Black staining.

Table 3. Distribution of canine hepatobiliary diseases

\begin{tabular}{|c|c|c|}
\hline Histopathological diagnosis & Number of cases & Percentage of total cases \\
\hline Hepatic displacements & 2 & $2.70 \%$ \\
\hline Vacuolar hepatopathy & 7 & $9.46 \%$ \\
\hline Hepatocellular steatosis & 3 & $4.06 \%$ \\
\hline Hepatocellular swelling & 2 & $2.70 \%$ \\
\hline Hepatic glycogenosis & 2 & $2.70 \%$ \\
\hline Necrosis & 2 & $2.70 \%$ \\
\hline Autolysis & 4 & $5.41 \%$ \\
\hline Circulatory disorders & 20 & $27.03 \%$ \\
\hline Passive congestion & 19 & $25.68 \%$ \\
\hline Peliosis hepatis (Telangiectasis) & 1 & $1.35 \%$ \\
\hline Hepatitis & 21 & $28.38 \%$ \\
\hline Acute hepatitis & 1 & $1.35 \%$ \\
\hline Subacute hepatitis & 7 & $9.46 \%$ \\
\hline Chronic hepatitis & 8 & $10.81 \%$ \\
\hline Cirrhosis & 3 & $4.06 \%$ \\
\hline Non-specific reactive hepatitis & 2 & $2.70 \%$ \\
\hline Cholangitis/Cholangiohepatitis & 1 & $1.35 \%$ \\
\hline Destructive cholangitis & 1 & $1.35 \%$ \\
\hline Proliferative lesions & 16 & $21.62 \%$ \\
\hline Hepatocellular adenoma and nodular hyperplasia & 1 & $1.35 \%$ \\
\hline Hepatocellular carcinoma & 2 & $2.70 \%$ \\
\hline Cholangiocellular carcinoma & 2 & $2.70 \%$ \\
\hline Combined hepatocellular and cholangiocellular carcinoma & 1 & $1.35 \%$ \\
\hline Primary hemangiosarcoma & 1 & $1.35 \%$ \\
\hline Metastatic lymphoma & 3 & $4.06 \%$ \\
\hline Metastatic histiocytoma & 1 & $1.35 \%$ \\
\hline Metastatic histiocytic sarcoma & 1 & $1.35 \%$ \\
\hline Metastatic giant cell fibrosarcoma & 1 & $1.35 \%$ \\
\hline Metastatic malignant myeloid tumor & 1 & $1.35 \%$ \\
\hline Metastatic multiple myeloma & 1 & $1.35 \%$ \\
\hline Metastatic malign melanoma & 1 & $1.35 \%$ \\
\hline No abnormality & 1 & $1.35 \%$ \\
\hline
\end{tabular}

* percentage of total cases: the number of cases of a diagnosis/the total number of cases $\times 100$. 

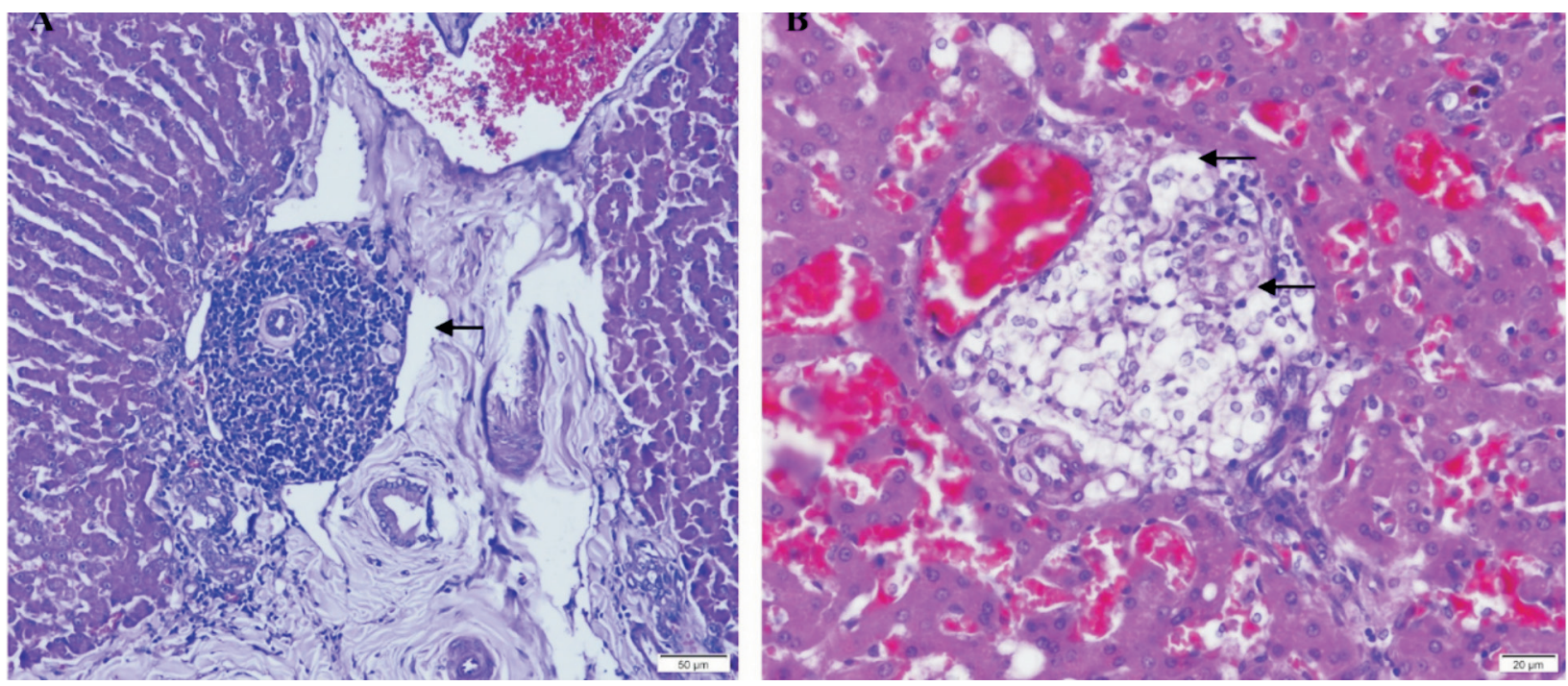

Fig. 2. Cholangitis. A - Lymphocytic cholangitis, Focal accumulation of lymphocytes around the bile duct (arrow), cat, H\&E. B - Destructive cholangitis, degenerated bile ducts (arrows), dog, H\&E.
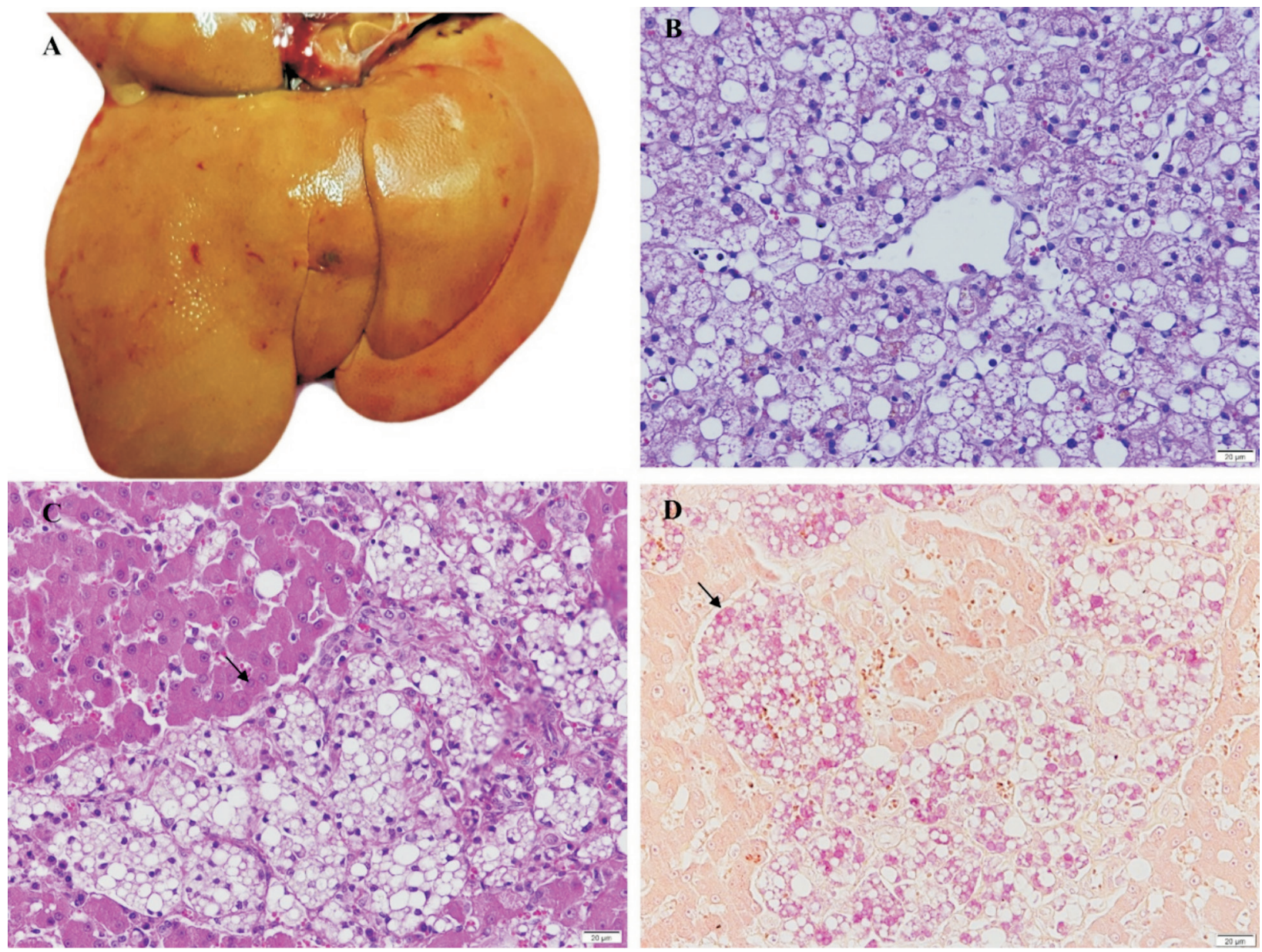

Fig. 3. Severe hepatocellular steatosis, cat. A - Yellow discoloration of the liver. B - Severe microvesicular and macrovesicular lipid vacuoles, H\&E. C - Lipogranuloma (arrow), H\&E. D - Positive staining of ceroid laden macrophages with AFIP staining method (arrow). 

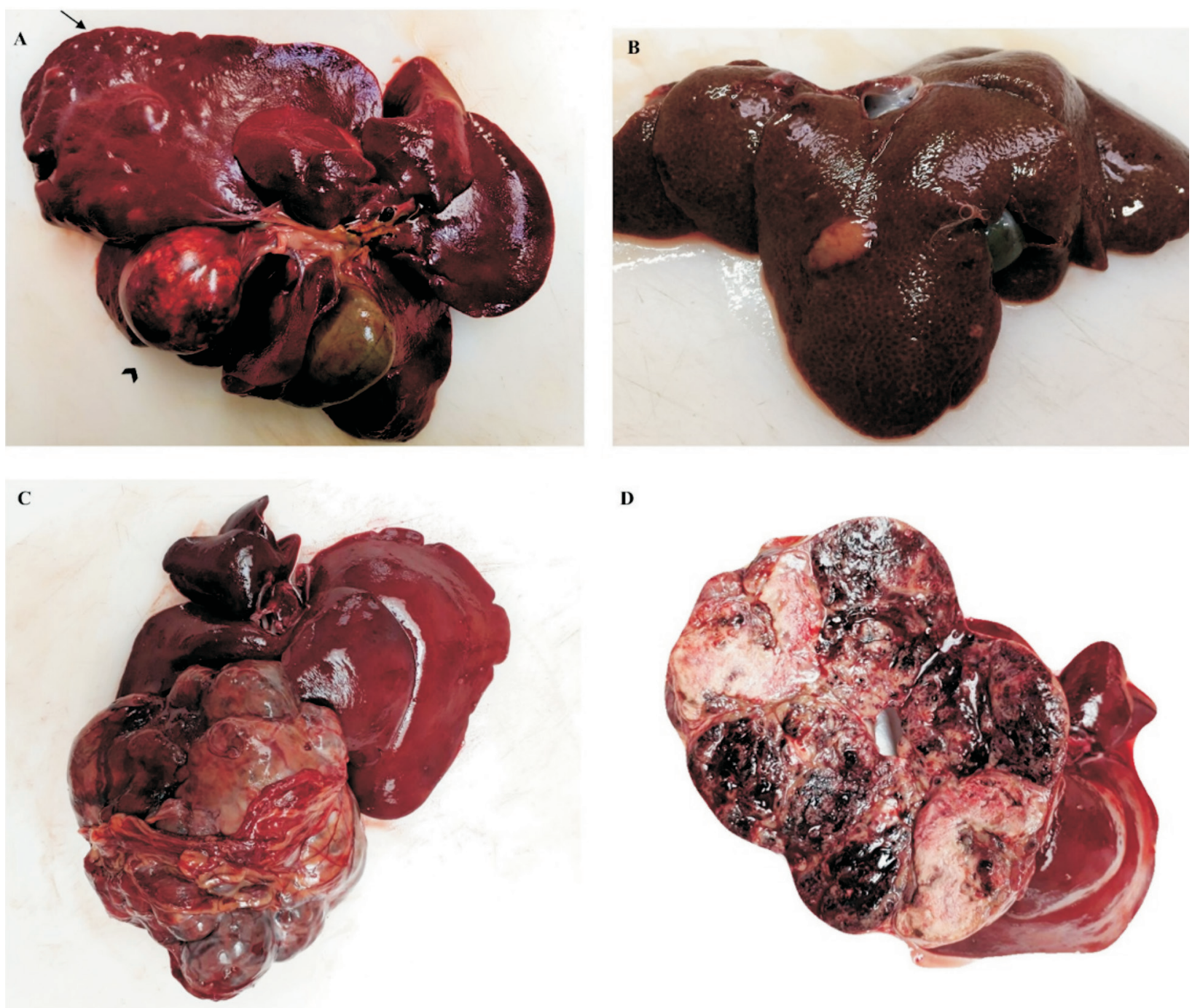

D

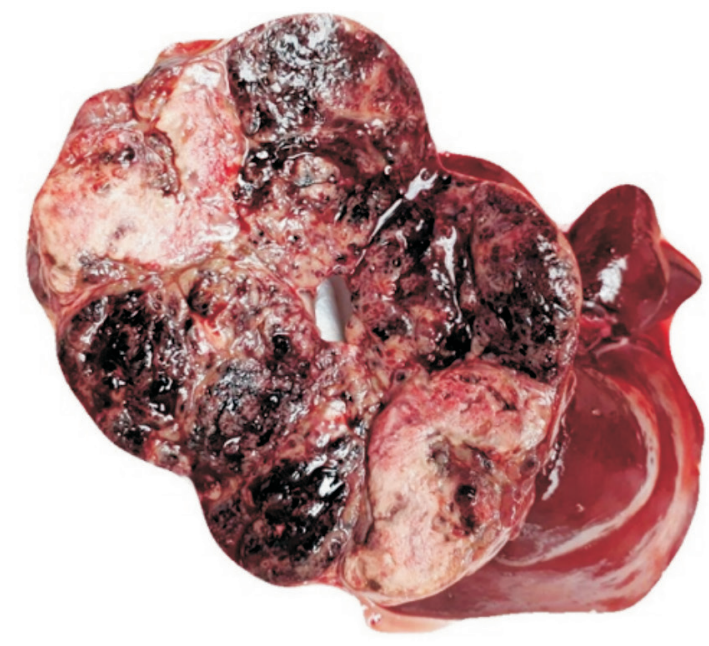

Fig. 4. Gross appearance of hepatocellular tumours. A - Multiple nodules of nodular hyperplasia bulging from the capsular surface of the liver (arrow) and a single white nodule of a hepatocellular adenoma (arrowhead), dog. B - A single white nodule of hepatocellular adenoma raised from the surface. C, D - Hepatocellular carcinoma involving the entire lobe with a multilobulated mottled cut surface, dog.

Cases were classified as either microvesicular or macrovesicular steatosis, according to the size of the cytoplasmic lipid vacuoles. While all canine cases were graded as severe hepatic lipidosis, feline cases were more diverse since there were 2 mild, 3 moderate and 4 severe cases of hepatic lipidosis. In 1 canine and 3 feline cases of severe and diffuse hepatocellular steatosis, lipogranulomas composed of foamy fat aggregations and ceroid laden macrophages were detected. The ceroid pigment was positively stained with PAS and AFIP staining methods (Fig. 3 D). The median age for feline hepatocellular steatosis was 5 years, and while females were more affected than males ( 5 cases, 55.56\%), there was no significant breed predisposition.

Passive congestion was diagnosed in six cats, which was $10.71 \%$ of the feline cases examined. As for canines, it was present in $27.03 \%$ of cases (20 of 74) and was the second most frequent liver lesion. Fifty-five percent of passive congestion cases had centrilobular necrosis, periacinar fibrosis, periportal hepatocytic lipidosis and hemosiderosis (hemosiderin was stained with blue pigment using 
Perl's Prussian Blue stain). These cases were diagnosed as chronic passive congestion and had a typical macroscopically distinct acinar pattern, known as a nutmeg appearance. Additionally, passive congestion was generally more grave in dogs with 7 severe, 9 moderate and 4 mild cases, compared to cats which showed moderate severity in 4 cases and mild severity in 2 cases. Passive congestion was found in dogs with a mean age of 4 years, and males (12 cases, 63.16\%) seemed more predisposed than females. Crossbreed dogs ranked highest (5/19 cases), and German Shepherds (3/19 cases) were second, together with Belgian Malinois (3/19 cases).
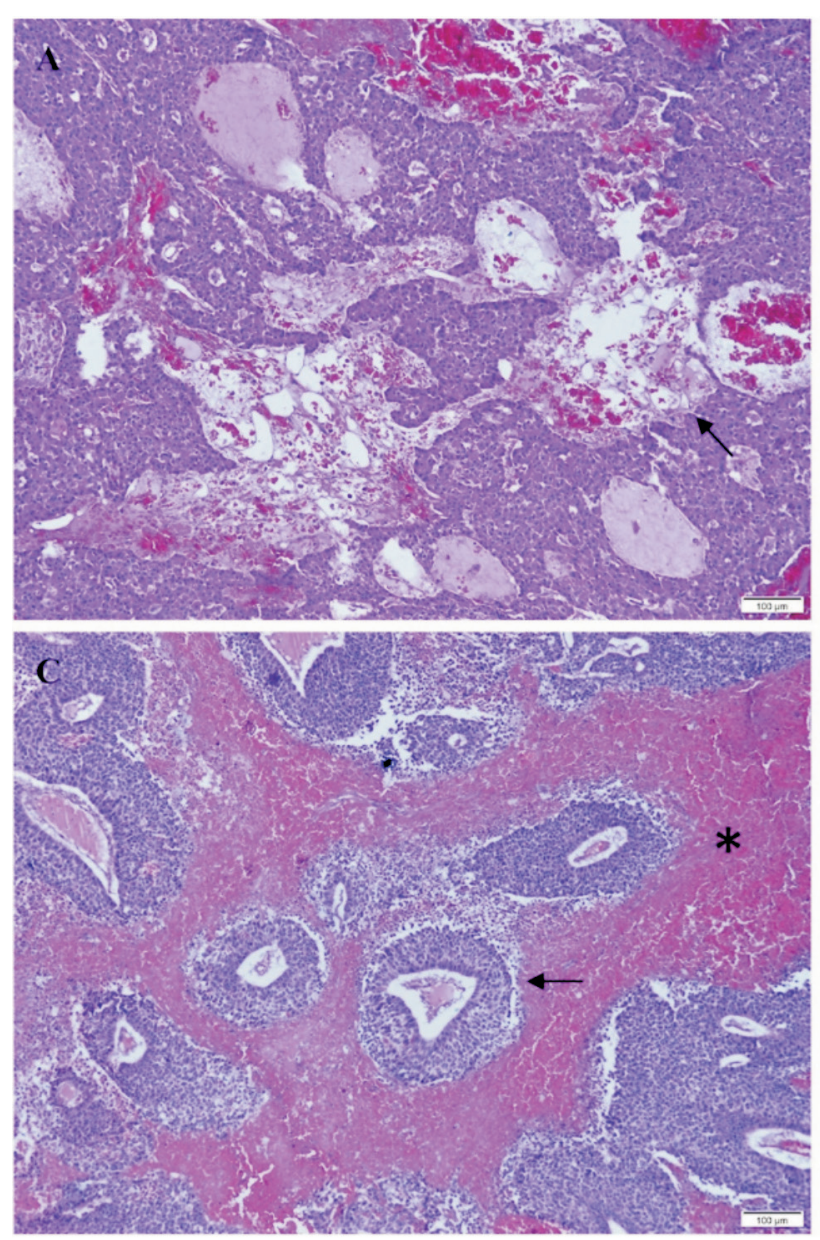

An Iranian cat with polycystic kidney disease was diagnosed with congenital polycystic liver disease. Histopathological examination of the case revealed portal-portal bridging fibrosis and prominent proliferation of the bile ducts beside the biliary cysts.

Proliferative liver lesions. Hepatic proliferative lesions were found in 4 cats $(7.14 \%)$ and 16 dogs $(21.62 \%)$. This was the third most frequent category in canine hepatic lesions. The distribution of proliferative lesions in cats and dogs is shown in Tables 2 and 3. Although the difference was not significant, secondary tumours (9 cases/12.16\%) were more frequent than primary tumours (7
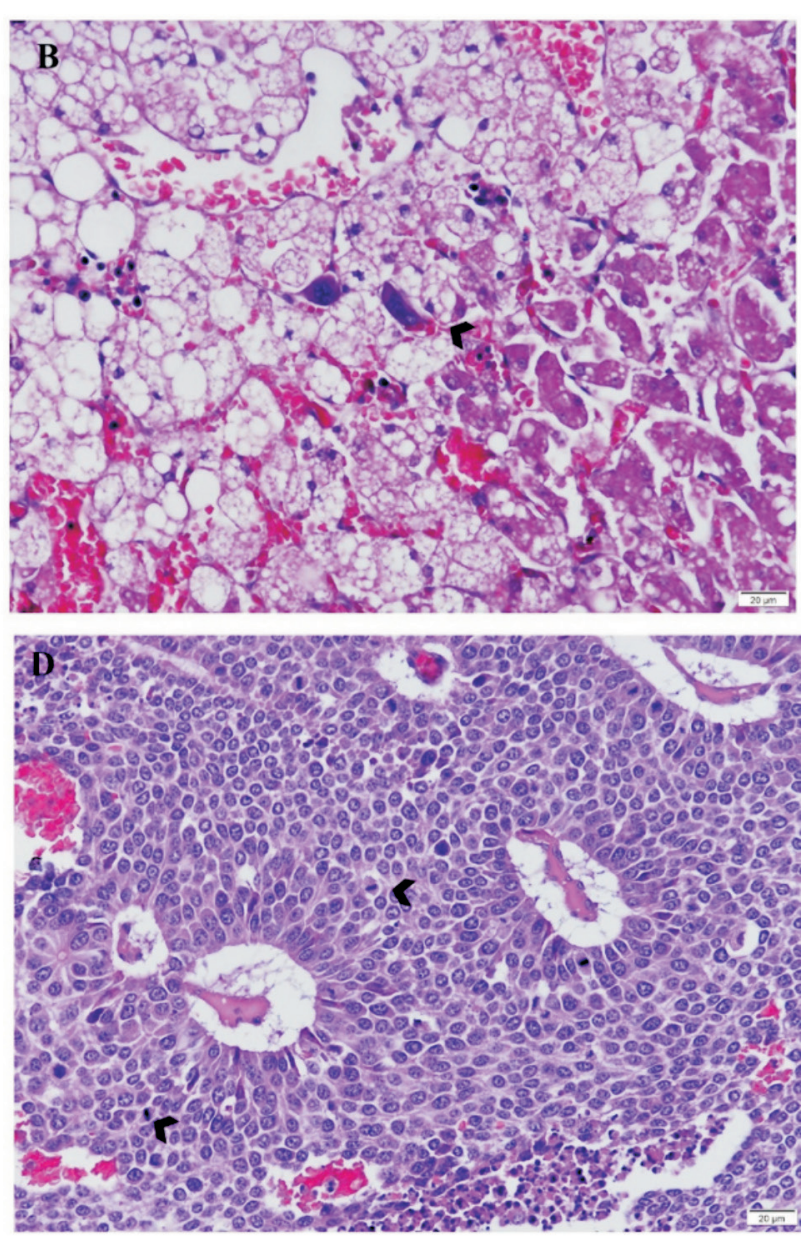

Fig. 5. A, B - Hepatocellular carcinoma, dog, H\&E. A - Cavern shaped vascular spaces (arrow) separating the hepatocellular neoplastic cells. B - Multinucleated cells most consistent with megakaryocytes (arrowhead). C, D Cholangiocellular carcinoma, dog, H\&E. C - Acini arrangement of biliary neoplastic cells (arrow) and vast necrotic areas (asterisk). D - Frequent mitotic Fig.s (arrowheads), H\&E. 
cases $/ 9.46 \%$ ) in dogs. Epithelial tumours accounted for the majority of canine primary hepatic tumours (6 cases), with only one case of primary hemangiosarcoma. Among the secondary tumours, metastatic lymphoma was most prominent for both species.

Primary hepatic tumours exhibited different general and histological appearances (Fig. 4, 5). Combined hepatocellular and cholangiocellular carcinoma was characterized by the presence of hepatocellular and cholangiocellular neoplastic cells. According to the WHO classification, this tumour is considered to be of the classical type, and its metastasis has been reported in the kidneys, lungs and heart (Bosman et al. 2018). Primary hemangiosarcoma and metastatic tumours of the liver had the same gross and histopathological findings as those arising in other organs. Among the six metastatic lymphoma cases, neoplastic lymphoid cells were localized in five cases in the portal tracts and surrounding the central veins. Only in one case were the neoplastic cells evenly scattered in the sinusoids.

Proliferative lesions appeared common among middle to senior aged dogs and cats, with a mean age of 10 years for both. Golden Retrievers had an increased risk of hepatic primary tumours (3/7 cases).
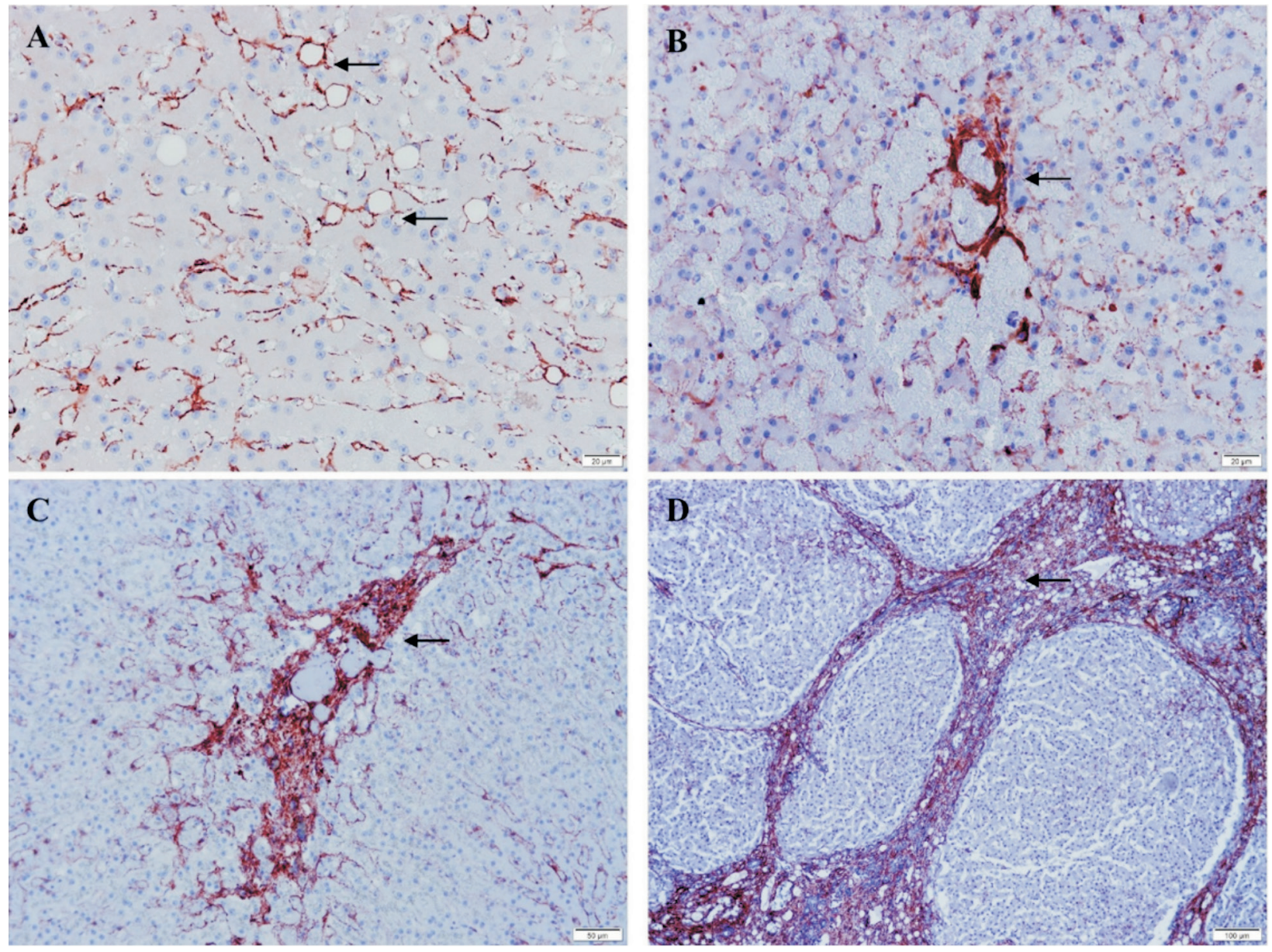

Fig. 6. $\alpha$-SMA expression in different hepatic diseases. A - Diffuse slight enlargement of the stellate cells (parenchymal myofibroblasts) with cytoplasmic lipid vacuoles in a few of them (arrows), hepatocellular steatosis, cat. B - Perivenular thickening of the stellate cells (arrow), passive congestion, dog. C - Moderate staining of the portal myofibroblasts (arrow), chronic hepatitis, dog. D - Intensive staining of the septal myofibroblasts (arrow) surrounding regenerative nodules, cirrhosis, dog. 
Hepatic fibrosis. In normal liver tissue sections, staining with $\alpha$-SMA antibody revealed mild cytoplasmic positivity throughout the parenchyma, in the form of thin irregular bands along the sinusoids (cytoplasmic extensions of hepatic stellate cells). A closer look revealed that these cells contained cytoplasmic lipid vacuoles. In the portal tracts, $\alpha$-SMA positive cells were found on the walls of the vena porta, arteria hepatica and around the bile ducts. Moreover, slight positive staining was observed in the borders of the central vein. Some large portal tracts were shown to have slightly positive portal myofibroblasts. Varying degrees of thickening of the parenchymal (stellate cells) and portal myofibroblasts were observed in different pathological conditions. In some cases, $\alpha$-SMA positive fibrous septa were reported bridging the portal areas and/or the central veins.

In general, cases with the highest $\alpha$-SMA positivity were canine cirrhosis, and primary and secondary tumours in both cats and dogs. In acute diseases, such as fulminant hepatitis, liquefactive necrosis, hepatocellular steatosis in cats, passive congestion and hepatic displacement in dogs, a slight increase in $\alpha$-SMA positive cells was observed. These cells were localized in the parenchyma (Fig. $6, A, B)$, and particularly at the injury sites of each condition. For example, $\alpha$-SMA positive cells showed perivenular localisation in cases of canine passive congestion (Fig. 6, B).

In feline and canine chronic hepatitis, although the highest number of $\alpha$-SMA positive cells was situated in the portal tracts (Fig. 6, C), parenchymal cells also showed positivity, but to a lesser extent. Similar to acute diseases, parenchymal positive cells were specifically located at necrotic and inflammatory sites. In some cases, $\alpha$-SMA positive cells located in the portal tracts, expanded and formed $\alpha$-SMA positive septa.

In canine cirrhosis, the highest number of $\alpha$-SMA positive cells was located in the septa surrounding the regenerative nodules, and replacing the damaged parenchyma (Fig. 6, D). Myofibroblasts located in the portal areas, at the interface of portal tracts and septa, were also intensively positive. No $\alpha$-SMA positive cells were seen in the regenerative nodules (Fig. 6, D). In feline lymphocytic cholangitis/ cholangiohepatitis, $\alpha$-SMA positive cells were specifically located in the portal areas.

In canine and feline tumour cases, the density and localization of positive myofibroblasts in the tumour sites and the surrounding parenchyma varied depending on the tumour type. The highest positive cell density was located in the portal and septal areas. Whether they were primary or secondary malignant tumours, they showed a higher number of $\alpha$-SMA positive cells than benign tumours. $\alpha$-SMA expression was higher in cholangiocellular carcinomas compared to hepatocellular carcinomas. Furthermore, in combined hepatocellular and cholangiocellular carcinomas, while no $\alpha$-SMA positive cells were encountered at the hepatocellular tumour sites, cholangiocellular tumour sites showed intensive $\alpha$-SMA expression.

In congenital polycystic liver disease, moderate $\alpha$-SMA expression was observed. Positive cells were located in the cyst walls, portal tracts, portalportal bridging septa, and parenchyma.

Statistical analysis. According to Pearson's chi-square test for testing the independence between $\alpha$-SMA and fibrosis classes, we used 95\% significant level and the p-value was 0.02458 for cats and 0.0122 for dogs, which means that $\alpha$-SMA and fibrosis are dependent on each other for cats and dogs. Thus, there is a significant relationship between these categorical variables. Also, using the same $\alpha$ level for the Pearson correlation test between $\alpha$-SMA and fibrosis in cats showed that the $r$ value was 0.71 , which means that they are $71 \%$ linearly related to each other for cats, and the $r$ value for dogs was 0.88 so they are also $88 \%$ linearly related to each other for dogs. Thus, $\alpha$-SMA and fibrosis classes are related to each other.

\section{Discussion and conclusions}

Considering the current literature, and on the basis of the WSAVA criteria (ROTHUIZEN et al 2006), this study pathomorphologically evaluated canine and feline hepatobiliary lesions, and simultaneously tracked their incidence in Turkey (Ankara region). Furthermore, hepatic fibrosis was histochemically and immunohistochemically evaluated under these different pathological conditions. 
This present study is the first histopathological evaluation of canine and feline hepatobiliary lesions in Turkey. We found a high incidence of hepatobiliary lesions in cats and dogs (98\%), proving that the liver is an organ greatly affected by various diseases in the body. The most frequent canine hepatobiliary lesions were hepatitis, passive congestion and vacuolar hepatopathy. In cats, hepatitis, hepatocellular lipidosis and cholangitis/ cholangiohepatitis were the most common liver lesions. These results showed similarities with retrospective studies previously performed in different countries (BAYTON et al. 2018, WANG et al. 2004, WARREN-SMITH et al. 2012).

Hepatitis had the highest occurrence in canine and feline hepatobiliary systems, which suggests the major exposure of cats and dogs in Ankara to infectious and toxic agents. In agreement with the reports of HIROSE et al. (2014) and POLDERVAAT et al. (2009), while chronic hepatitis was more common in dogs, acute hepatitis and non-specific reactive hepatitis were more common in cats. Subacute hepatitis had similar prevalence in cats and dogs, while cirrhosis cases were only detected in dogs.

This study, along with previous studies (HIROSE et al. 2014, BEXFIELD et al. 2012), indicates that chronic hepatitis and cirrhosis are diseases that are common among middle-aged and older dogs, with a median age of 10 years. Females outnumbered males, which is consistent with other studies. Breeds with a high incidence of chronic hepatitis and cirrhosis were German Shepherd, Golden Retriever and crossbreed dogs. Breed predispositions, as reported in the literature, include American and English Cocker Spaniels, Labradors, Golden Retrievers, Doberman Pinschers, West Highland White Terriers, English Springer Spaniels, Yorkshire and Jack Russell Terriers (HIROSE et al. 2014, POLDERVAAT et al. 2009, WATSON et al. 2010, KANEMOTO et al. 2013).

Non-specific reactive hepatitis, which was more frequently diagnosed in cats, was histopathologically characterized by the absence of hepatocellular necrosis. Studies investigating nonspecific reactive hepatitis reported that it arises in response to diseases affecting the urinary, genital, cardiovascular, respiratory, digestive and endocrine systems (BAYTON et al. 2018, NEUMANN and DANNER 2012). Moreover, the fact that affected cats in the present study had a median age of 4 months can be linked to vulnerability to infections due to an incomplete vaccination program.

Cholangitis/cholangiohepatitis has been shown several times in studies as a disease of feline species (BAYTON et al. 2018, WANG et al. 2004, HIROSE et al. 2014, GAGNE et al. 1996). This was also the case in this study, where cholangitis was the second most frequent lesion in cats, with only one case seen in dogs. All cholangitis/ cholangiohepatitis were diagnosed as lymphocytic, which contradicts previous studies that considered neutrophilic cholangitis as the most common form of the disease in cats (BAYTON et al. 2018, HIROSE et al. 2014, CLARK et al. 2011).

The incidence of hepatocellular lipidosis, which has been reported more frequently in cats compared to dogs, was noted to be higher than that reported in Japan and the UK (BAYTON et al. 2018, HIROSE et al. 2014), but lower than in the USA (ARMSTRONG and BLANCHARD 2009). The median age of cats in this study was 5 years old, which is the same as reported by AKOL et al. (1993). KUZI et al. (2017) on the other hand reported a median age of 7 years. An over-representation of females was found by both studies previously mentioned (AKOL et al. 1993, KUZI et al. 2017), which is in alignment with this study, where female cats outnumbered males. No breed predisposition was found, which contradicts a previous association with British Shorthair according to the previously mentioned studies. This may be due to the lower population of this breed in Turkey compared to other countries.

Proliferativelesions of the liverarepredominantly reported in dogs in this study. Previous literature on canine hepatic proliferative lesions indicated the predominance of primary tumours versus secondary tumours (CULLEN and STALKER 2016, CULLEN 2017). However, no distinct difference between the ratio of canine primary and secondary hepatic neoplasms was found here. According to HIROSE et al. (2014) and WARREN-SMITH et al. (2012), the most frequent canine primary hepatic neoplasms were hepatocellular adenoma and carcinoma. In the present study, hepatocellular and cholangiocellular carcinomas were the most frequent. Among the metastatic tumours, the most common tumours in both cats and dogs were lymphomas. In accordance with CULLEN (2017), 
neoplastic lymphoid cells showed predominant portal and perivenular infiltration of the liver.

Hepatic fibrosis is a common reaction to persistent hepatic injury, and is associated with a wide variety of diseases. Myofibroblasts are cells that play a major role in fibrosis of most organs (CARPINO et al. 2005, VLADIMIR 2014). This study investigated the immunohistochemical properties of hepatic stellate cells and portal/septal myofibroblasts. It also demonstrated, in accordance with previous studies (IJZER et al. 2006), that $\alpha$-SMA is a suitable antibody to identify hepatic myofibroblasts.

In humans and rats, hepatic stellate cells are only positive when activated (IJZER et al. 2006, VLADIMIR 2014). Unlike in humans and rodents, IJZER et al. (2006) reported in dogs that whether activated or resting, stellate cells and portal myofibroblasts show positive staining with $\alpha$-SMA antibody. This was explained by the fact that canine myofibroblasts are more involved in the regulation of hepatic sinusoidal flow than in other species. In this study also, resting stellate cells and portal myofibroblasts slightly expressed $\alpha$-SMA in both feline and canine livers. This finding proved that the distinction between activated and resting hepatic myofibroblasts in dogs and cats is made by examination of their morphological and functional changes.

The severity of fibrosis was staged in canine and feline sections stained with Masson's Trichome stain, on the basis of a modified staging system for fibrosis. The statistical analysis between fibrosis staging and immunohistochemical expression of $\alpha$-SMA per case showed a definite positive correlation. While MEKONNEN et al. (2007) also found a positive correlation between histochemically staged fibrosis and immunohistochemical myofibroblast expression, IJZER et al. (2006) and BOISCLAIR et al. (2001) reported a negative correlation.

Immunohistochemical investigation of different hepatic lesions showed that stellate cells lost their lipid vacuoles and gained the phenotype of myofibroblasts by transforming into spindle shaped cells. Portal and septal myofibroblasts also showed various degrees of activation. Both the intensity and the localization of positive myofibroblasts changed with lesion type. In acute canine and feline events (fulminant hepatitis, liquefactive necrosis and hepatocellular steatosis), stellate cells (parenchymal myofibroblasts) were greatly activated in the damaged areas. In canine and feline chronic hepatitis, both portal myofibroblasts and parenchymal myofibroblasts located at the damaged areas were activated. As the disease became chronic, portal myofibroblasts became thicker and formed bridging septa. In canine cirrhosis, septal myofibroblasts were predominantly activated, and the absence of myofibroblasts in hyperplastic nodules was observed. These observations are consistent with those reported by SCHOTANUS et al. (2009). In feline lymphocytic cholangitis/cholangiohepatitis cases, portal myofibroblasts were the main activated cells. Activation of myofibroblasts and their densities showed great variation between cases in both feline and canine tumours.

In general, the increase in necrosis and fibrosis (due to the damage to the parenchyma caused by the tumour) was the same for myofibroblasts, especially portal/septal myofibroblasts, which as a result became more active than other myofibroblast groups. In feline congenital polycystic disease, the localization of $\alpha$-SMA positive cells in the cyst walls, portal tracts, parenchyma and portal-portal bridging septa, suggests that it is due to juvenile or congenital fibrosis. According to the terminology proposed by the WSAVA (ROTHUIZEN et al. 2006), these cases have been defined as juvenile polycystic disease/congenital hepatic fibrosis.

In conclusion, hepatic myofibroblasts proved to play a major cell role in liver fibrosis, changing their type and intensity according to the hepatobiliary lesion. While parenchymal myofibroblasts were more dominant in acute liver diseases, portal and septal myofibroblasts were more prevalent in chronic liver diseases.

This study can be used as a reference point for future pathological surveys since there is a lack of histopathological surveys related to canine and feline hepatobiliary diseases in Turkey. Similar studies are of great importance, not only for diagnosis and prevention but also for an understanding of the incidence and pathological features of hepatobiliary diseases.

\section{Acknowledgments}

This study was carried out for the first author's PhD thesis. Funding for this study was provided by the Ankara University Scientific Research Projects Coordination Unit, Project number: 17L0239005. 


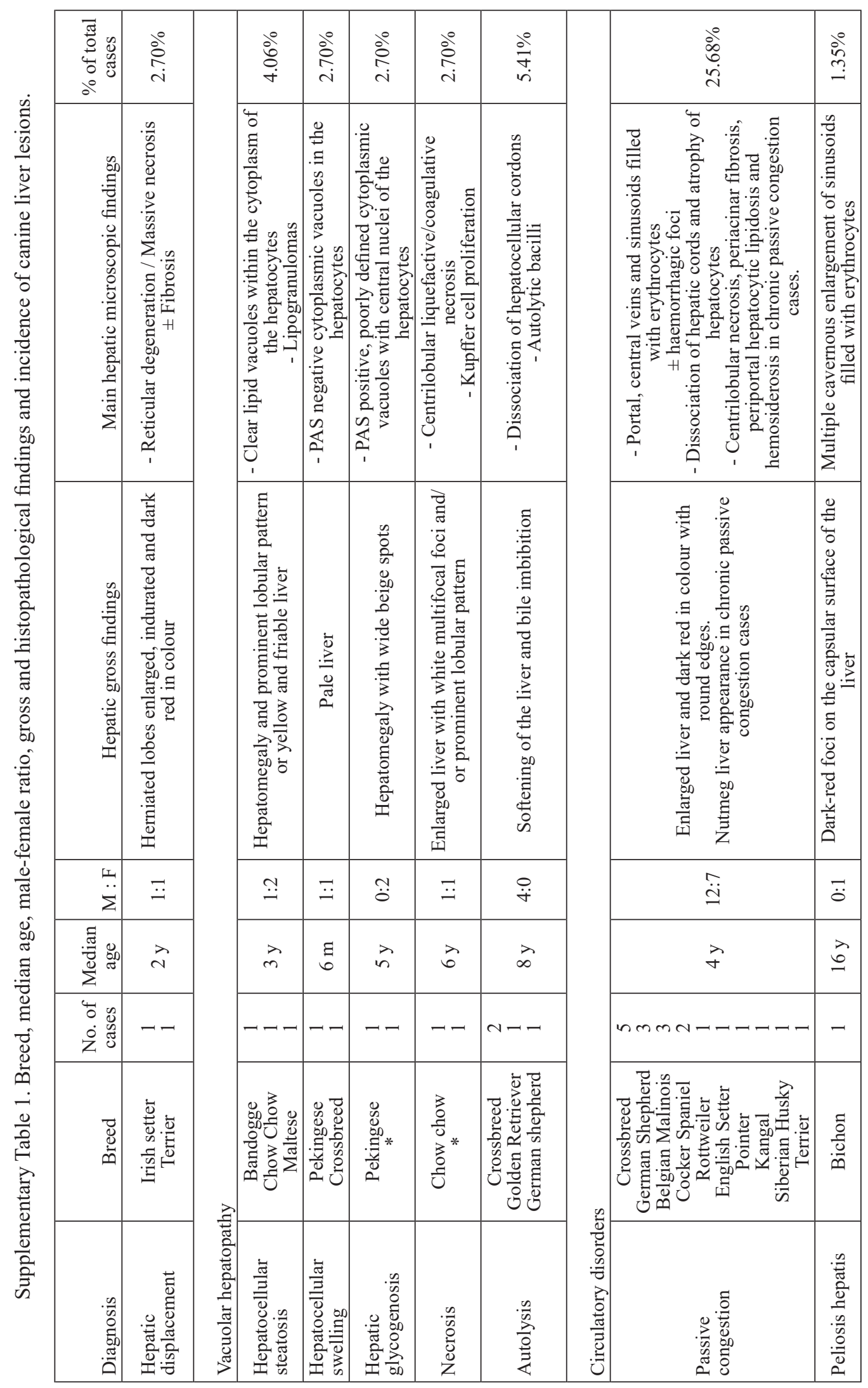




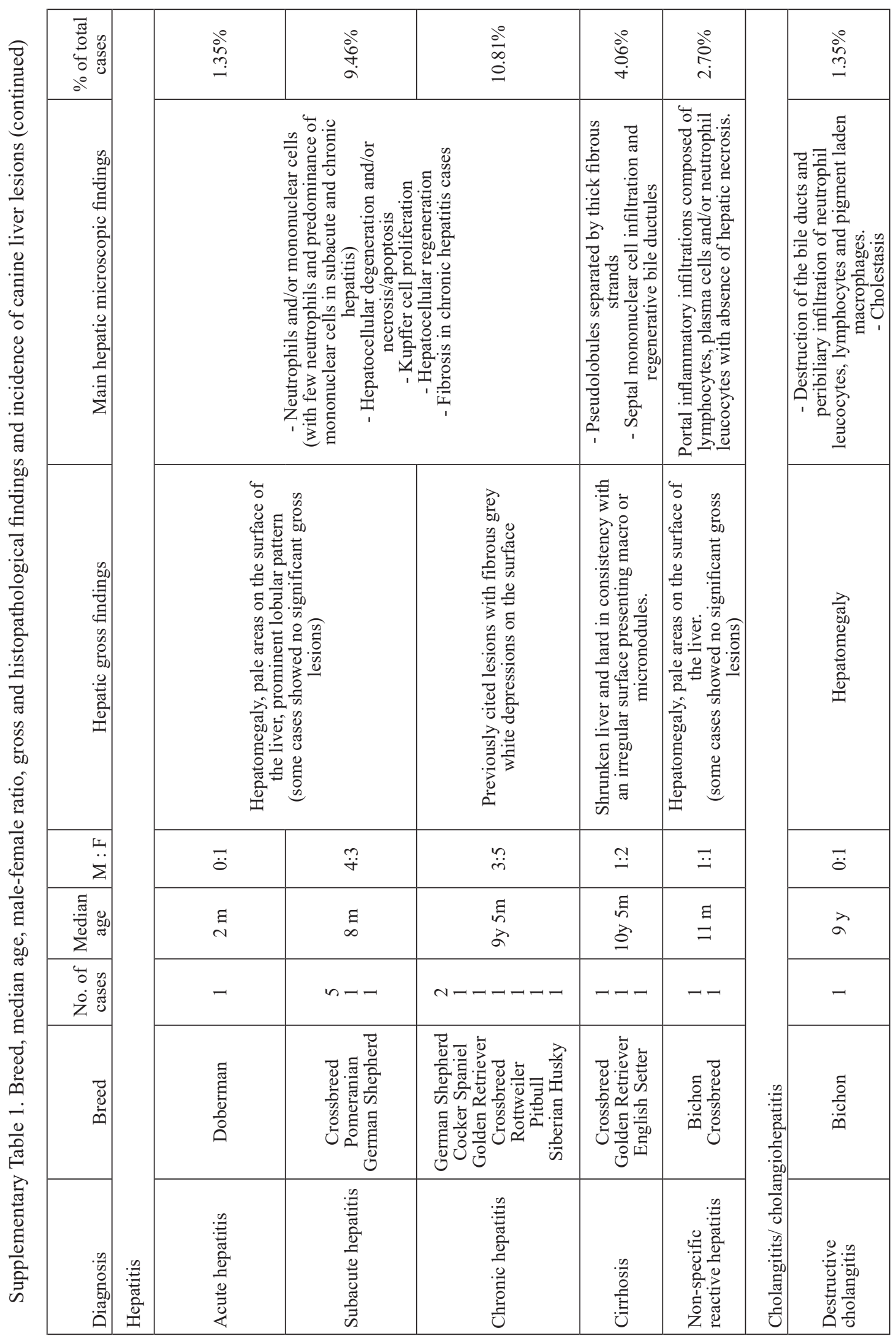




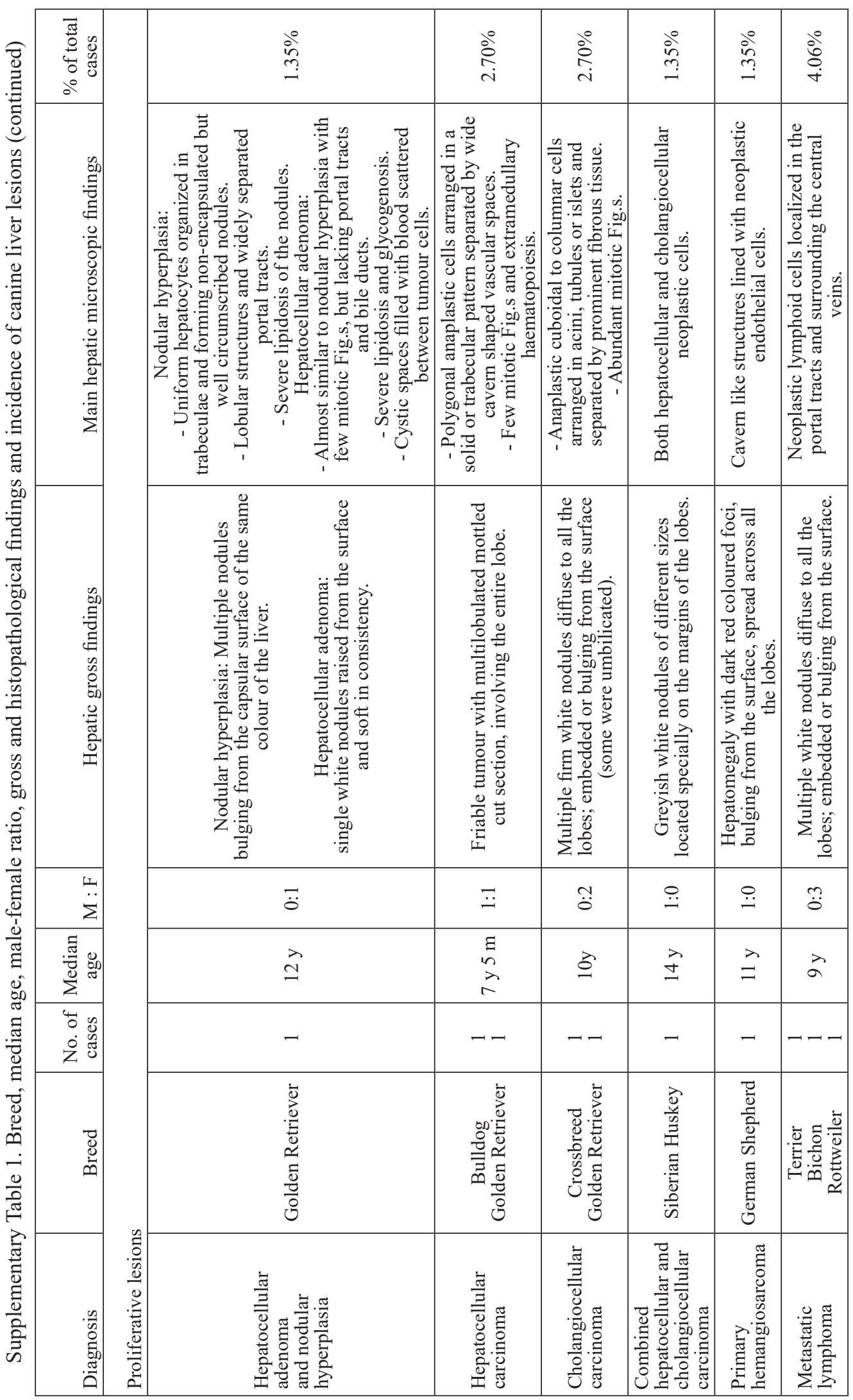




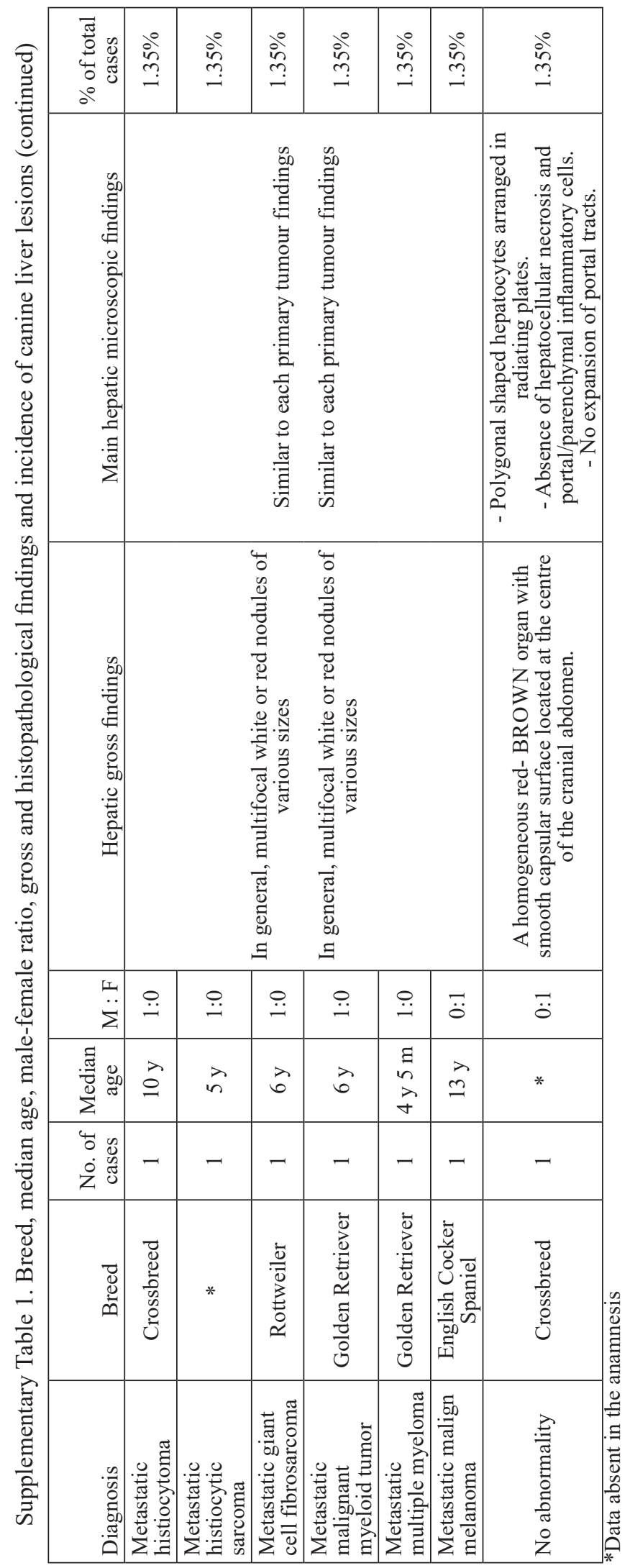




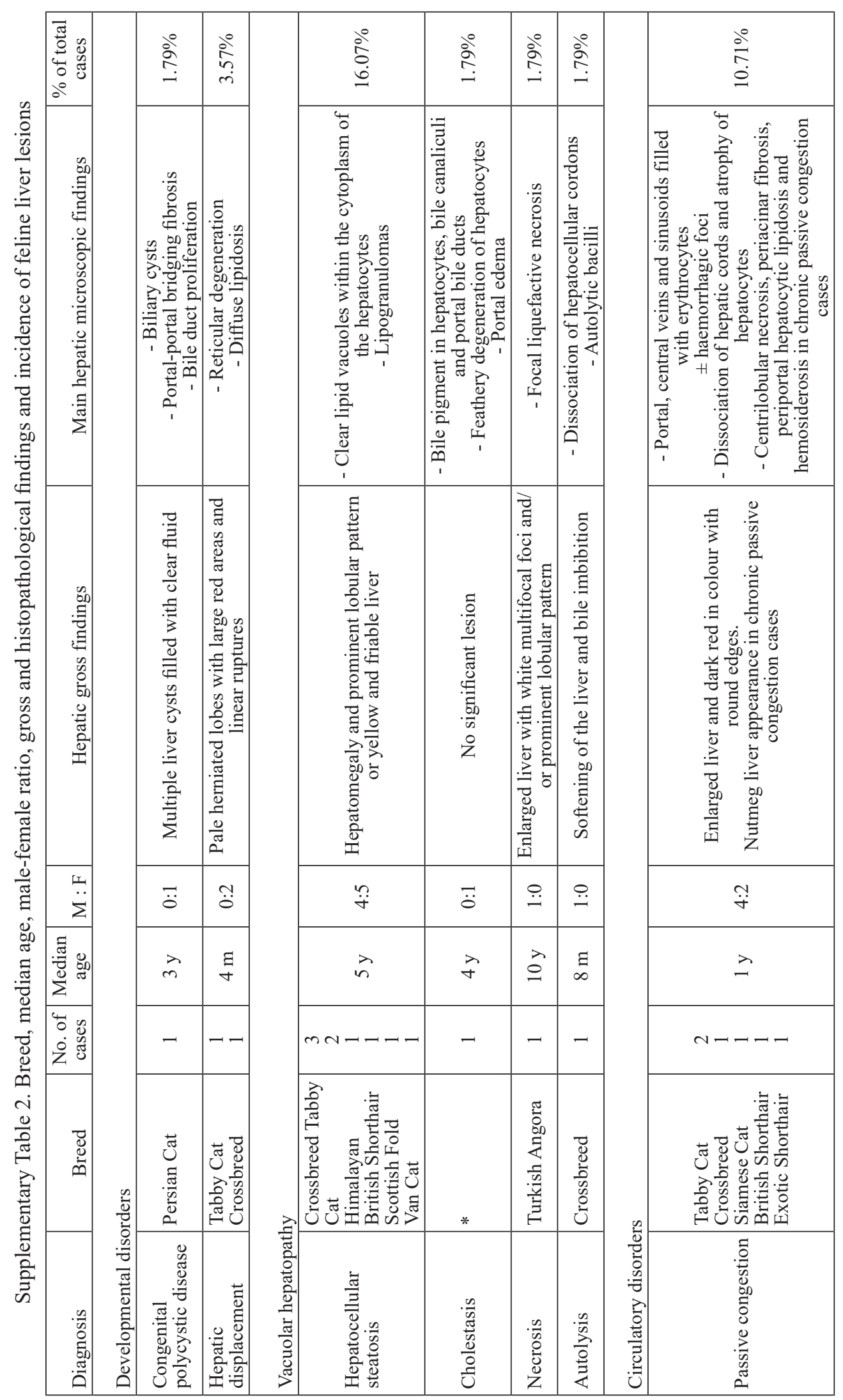




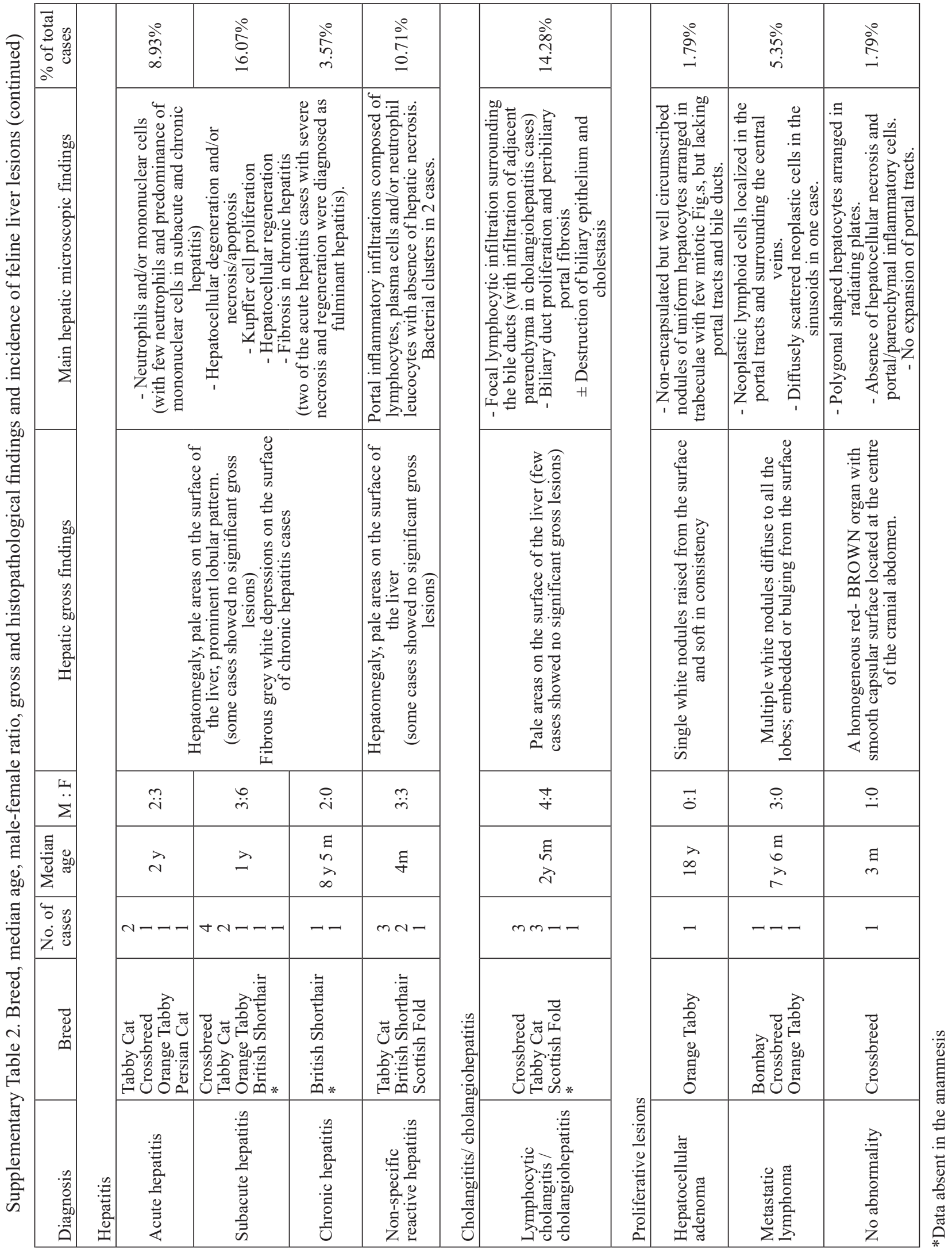




\section{References}

AKOL, K. G., R. J. WASHABAU, H. M. SAUNDERS, M. J. HENDRICK (1993): Acute pancreatitis in cats with hepatic lipidosis. J. Vet. Intern. Med. 7, 205-209.

DOI: 10.1111/j.1939-1676.1993.tb01008.x

ARMSTRONG, P. J., G. BLANCHARD (2009): Hepatic lipidosis in cats. Vet. Clin. North. Am. Small Anim. Pract. 39, 599-616.

DOI: $10.1016 /$ j.cvsm.2009.03.003

BAYTON, W. A., C. WESTGARTH, T. SCASE, D. J. PRICE, N. H. BEXFIELD (2018): Histopathological frequency of feline hepatobiliary disease in the UK. J. Small Anim. Pract. 59, 404-410.

DOI: 10.1111 jsap. 12810

BEXFIELD, N. H., R. J. BUXTON, T. J. VICEK, M. J. DAY, S. M. BAILEY, S. P. HAUGLANDE, L. R. MORRISON, R. W. ELSE, F. CONSTANTINO-CASASA, P. J. WATSONA (2012): Breed, age and gender distribution of dogs with chronic hepatitis in the United Kingdom. Vet. J. 193, 124-128. DOI: 10.1016/j.tvj1.2011.11.024

BOISCLAIR, J., M. DORE, G. BEAUCHAMP, L. CHOUINARD, C. GIRARD (2001): Characterization of the inflammatory infiltrate in canine chronic hepatitis. Vet. Pathol. 38, 628-635.

DOI: $10.1354 /$ vp.38-6-628

BOSMAN F. T., F. CARNEIRO, R. HRUBAN, N. D. THEISE (2010): WHO Classification of Tumours of the Digestive System. $4^{\text {th }}$ ed., World Health Organization.

BROWN, D. L., A. J. VAN WETTERE, J. M. CULLEN (2017): Hepatobiliary System and Exocrine Pancreas. In: Pathologic Basis of Veterinary Disease (Zachary, J. F., Ed.), 6th ed, Elsevier, St. Louis, Missouri, pp. 412-470.

DOI: 10.1016/B978-0-323-35775-3.00008-4

CARPINO, G., S. MORINI, S. G. CORRADINI, A. FRANCHITTO, M. MERLI, M. SICILIANO, F. GENTILI, A. ONETTI MUDA, P. BERLOCO, M. ROSSI, A. F. ATTILI, E. GAUDIO (2005): Alpha-SMA expression in hepatic stellate cells and quantitative analysis of hepatic fibrosis in cirrhosis and in recurrent chronic hepatitis after liver transplantation. Dig. Liver Dis. 37, 349-356.

DOI: 10.1016/j.dld.2004.11.009

CLARK, J. E. C., J. L. HADDAD, D. C. BROWN, M. J. MORGAN, T. J. VAN WINKLE, M. P. RONDEAU (2011): Feline cholangitis: a necropsy study of 44 cats (1986-2008). J. Feline Med. Surg. 13, 570-576.

DOI: $10.1016 /$ j.jfms.2011.05.002

CULLEN, J. M., M. J. STALKER (2016): Liver and Biliary System. In: Jubb, Kennedy, and Palmer's Pathology of Domestic Animals (Grant Maxie, M., Ed.), $6^{\text {th }}$ ed, Elsevier, St. Louis, Missouri, USA, pp. 259-351.

DOI: 10.1016/B978-0-7020-5318-4.00008-5
CULLEN, J. M. (2017): Tumors of the liver and gallbladder. In: Tumors in Domestic Animals (Meuten, D. J., Ed.), $5^{\text {th }}$ ed, John Wiley \& Sons Inc, Iowa, USA, pp. 602-631.

DOI: $10.1002 / 9781119181200 . c h 14$

GAGNE, J. M., D. J. WEISS, P. J. ARMSTRONG (1996): Histopathologic evaluation of feline inflammatory liver disease. Vet. Pathol. 33, 521-526.

DOI: $10.1177 / 030098589603300506$

GOODMAN, Z. D. (2007): Grading and staging systems for inflammation and fibrosis in chronic liver diseases. J. Hepatol. 47, 598-607.

DOI: $10.1016 /$ j.jhep.2007.07.006

HIROSE, N., K. UCHIDA, H. KANEMOTO, K. OHNO, J. K. CHAMBERS, H. NAKAYAMA (2014): A retrospective histopathological survey on canine and feline liver diseases at the University of Tokyo between 2006 and 2012. J. Vet. Med. Sci. 76, 1015-1020.

DOI: 10.1292/jvms.14-0083

IJZER, J., T. ROSKAMS, R. F. MOLENBEEK, T. ULTEE, L. C. PENNING, J. ROTHUIZEN, T. S. VAN DEN INGH (2006): Morphological characterisation of portal myofibroblasts and hepatic stellate cells in the normal dog liver. Comp. Hepatol. 5, 7.

DOI: 10.1186/1476-5926-5-7

ISHAK, K., A. BAPTISTA, L. BIANCHI, F. CALLEA, J. DE GROOTE, F. GUDAT, H. DENK, V. DESMET, G. KORB, R. N. M. MACSWEENI, M. J. PHILLIPS, B. G. PORTMANNL, H. PAULSEN, P. SCHEUER, M. SCHMID, H. THALER (1995): Histological grading and staging of chronic hepatitis. J. Hepatol. 22, 696-699.

DOI: 10.1016/0168-8278(95)80226-6

KANEMOTO, H., M. SAKAI, Y. SAKAMOTO, B. SPEE, T. S. G. A. M. VAN DEN INGH, B. A. SCHOTANUS, K. OHNO, J. ROTHUIZEN (2013): American cocker spaniel chronic hepatitis in Japan. J. Vet. Intern. Med. 27, 10411048 .

DOI: 10.1111 jvim. 12126

KUTLU, T., G. ALCIGIR (2019): Comparison of renal lesions in cats and dogs using pathomorphological and immunohistochemical methods. Biotech. Histochem. 94, 126-133.

DOI: $10.1080 / 10520295.2018 .1522670$

KUZI, S., G. SEGEV, S. KEDAR, E. YAS, I. AROCH (2017): Prognostic markers in feline hepatic lipidosis: A retrospective study of 71 cats. Vet. Rec. 181, 512.

DOI: $10.1136 /$ vr.104252

LUNA, L. G. (1968): Manual of Histological Staining Methods of the Armed Forces Institute of Pathology. $3^{\text {rd }}$ ed., McGraw Hill Book Company, New York, USA, pp. 186.

MEKONNEN, G. A., J. IJZER, H. NEDERBRAGT (2007): Tenascin-C in chronic canine hepatitis: immunohistochemical localization and correlation with 
necro-inflammatory activity, fibrotic stage, and expression of alpha-smooth muscle actin, cytokeratin 7, and CD3+ cells. Vet. Pathol. 44, 803-813.

DOI: $10.1354 / \mathrm{vp} .44-6-803$

MILLER, R. T. (2001): Technical immunohistochemistry: achieving reliability and reproducibility of immunostains. Soc. Appl. Immunohistochem. 56.

NEUMANN, S., W. DANNER (2012): Reactive hepatitis in dogs. Glob. Vet. 9, 454-459.

DOI: 10.5829/idosi.gv.2012.9.4.653

POLDERVAART, J. H., R. P. FAVIER, L. C. PENNING, T. S. G. A. M. VAN DEN INGH, J. ROTHUIZEN (2009): Primary hepatitis in dogs: a retrospective review (20022006). J. Vet. Intern. Med. 23, 72-80.

DOI: $10.1111 / \mathrm{j} .1939-1676.2008 .0215 . \mathrm{x}$

ROTHUIZEN, J., S. BUNCH, J. CHARLES (2006): WSAVA Standards for Clinical and Histological Diagnosis of Canine and Feline Liver Diseases, Elsevier Health Sciences, Philadelphia, USA.

SCHOTANUS, B. A., T. S. VAN DEN INGH, L. C. PENNING, J. ROTHUIZEN, T. A. ROSKAMS, B. SPEE (2009): Cross-species immunohistochemical investigation of the activation of the liver progenitor cell niche in different types of liver disease. Liver Int. 29, 1241-1252.

DOI: $10.1111 /$ j.1478-3231.2009.02024.x
VINCE,A.R.,M.A.HAYES, B.J.JEFFERSON,M.J.STALKER (2016): Sinusoidal endothelial cell and hepatic stellate cell phenotype correlates with stage of fibrosis in chronic liver disease in dogs. J. Vet. Diagn. Invest. 28, 498-505. DOI: $10.1177 / 1040638716658499$

VLADIMIR, K. (2014): Myofibroblasts in normal and fibrotic liver in different animal species. Acta Vet. 64, 397-412.

DOI: 10.2478 acve-2014-0038

WANG, K. Y., D. L. PANCIERA, R. K. AL-RUKIBAT, Z. A. RADI (2004): Accuracy of ultrasound-guided fine-needle aspiration of the liver and cytologic findings in dogs and cats: 97 cases (1990-2000). JAVMA 224, 75-78.

DOI: $10.2460 /$ javma.2004.224.75

WARREN-SMITH, C. M. R., S. ANDREW, P. MANTIS, C. R. LAMB (2012): Lack of associations between ultrasonographic appearance of parenchymal lesions of the canine liver and histological diagnosis. J. Small Anim. Pract. 53, 168-173.

DOI: $10.1111 / \mathrm{j} .1748-5827.2011 .01184 . \mathrm{x}$

WATSON, P. J., A. J. A. ROULOIS, T. J. SCASE, R. IRVINE, M. E. HERRTAGE (2010): Prevalence of hepatic lesions at post-mortem examination in dogs and association with pancreatitis. J. Small Anim. Pract. 51, 566-572.

DOI: $10.1111 /$ j.1748-5827.2010.00996.x

Received: 18 March 2020

Accepted: 23 June 2020

\section{ABOU MONSEF, Y., O. KUTSAL: Patomorfološka procjena hepatobilijarnih lezija u pasa i mačaka uzgojenih na području grada Ankare. Vet. arhiv 91, 359-378, 2021. \\ Sažetak}

Cilj ovog rada bio je istražiti patološke poremećaje hepatobilijarnog sustava u pasa i mačaka uzgajanih na području grada Ankare, te odrediti vrstu i učestalost promatranih lezija. Osim toga cilj je bio utvrditi regeneraciju jetre kao reakciju na ozljedu u različitim hepatobilijarnim lezijama primjenom imunohistokemijskih metoda. Makroskopski i mikroskopski su pretraženo jetre od 56 mačaka i 74 psa nakon postmortalne analize. Uzorci s jetrenom fibrozom imunohistokemijski su obojeni protutijelima $\alpha$-SMA. Lezije su nađene u $98 \%$ jetara pretraženih pasa i mačaka. U mačaka je najčešća histopatološka dijagnoza bio hepatitis (39,28 \%), hepatocelularna lipidoza (16,07 \%) i kolangitis/ kolangiohepatitis $(14,28 \%)$. U pasa je najčešći bio hepatitis $(28,38 \%)$, zatim pasivna kongestija $(25,68 \%)$ i proliferativne lezije $(21,62 \%)$. Za neke su hepatobilijarne lezije promatrani pasminska, dobna i spolna predispozicija. Imunohistokemijski $\alpha$-SMA protutijela pozitivno su obojila parenhimske, portalne i septalne miofibroblaste. Dokazana je pozitivna korelacija među rezultatima imunohistokemije pomoću $\alpha$-SMA i histokemijske fibroze. Ovo je prvo istraživanje u Turskoj koje donosi i incidenciju hepatobilijarnih lezija u mačaka i pasa i njihova patomorfološka svojstva. Kad je riječ o regeneraciji, promatrana je važna uloga jetrenih miofibroblasta u jetrenoj fibrozi. Pronađena je varijacija u intenzitetu i lokaciji pozitivno objenih stanica s obzirom na vrstu lezije. Zaključak ovog istraživanja jest da treba obratiti pozornost na određene jetrene lezije u pasa i mačaka što pruža referentnu normu za daljnja klinička i histopatološka istraživanja.

Ključne riječi: pas; mačka; hepatobilijarni sustav; imunohistokemija; patomorfologija 